\section{RED FOX PREDATED BY SNOWY OWL}

by CHARLES C. DIXON*

On December 19, 1974, on River bt 417 in the Rural Municipality of orris, Manitoba, I observed a female owy Owl that had apparently atcked and killed a male Red Fox. hen first observed at about 10:00 $\mathrm{m}$. the owl was sitting on the ground ughly 5 feet from the fox. The fox rcass was still warm and bleeding.

The fox, an adult male, in excellent ysical condition (10 lbs., $14 \mathrm{oz}$.) cd from massive hemorrhaging in e lumbar (kidney) and cervical eck) regions. I recorded 63 talon nctures in the dorsal and 21 in the ntral areas of the fox carcass. There s no evidence that the owl attemp1 to feed on the kill or was in any y injured during the engagement.

The habitat was a lightly snowed falfa field several hundred yards m a hydro line commonly used as a rch area by Snowy Owls. The closest ody cover is $3 / 4$ mile east on the nks of the Red River.

David Hatch in Chickadee Notes ec. 21, 1974, Winnipeg Free Press) cuments the earliness and pertence of Snowy Owl migrations rough Manitoba in the last several ars. He notes Eskimo references to edation on the much smaller Arctic $x$ by Snowy Owls. Predation on Red $x$, however, must be rare.

itorial Note: The following received m David R. M. Hatch provides eful additional information and

esources Project,

ept. Mines, Resources and ivironmental Management,

301 Ellice Ȧve.,

innipeg, Manitoba.

3G OG I speculation on this unusual observation.

"There is a great deal of variation in the status of mouse populations within the province. In some locations, particularly the boreal regions of southeastern Manitoba, mice are abundant. In the neighbouring Red River valley just the opposite is true. Manmade causes are the main reason for this dearth of mice. The land in this region is intensively farmed for the production of cereal grains and special crops. The fall of 1974 was drier and milder than normal and, consequently, the farmers were able to turn under all their stubble. There are virtually no fields that were not worked last fall. This means that habitat for mice is at a premium and about the only place they can live is along the road allowances. Definitely there is a shortage of rodents on which Snowy Owls can prey within the entire Red River flood plains and this probably explains why the owl attacked such large prey.

"I speculate that the actual cause of death was the hemorrhaging of the kidneys. It is also important to note that the fox was a fat specimen and showed no signs of a previous injury, such as broken bones from hitting a vehicle or lead from being shot. If the fox had sustained previous injury, then it would have been more prone to attack by an owl.

"Finally, I am not surprised that the owl had not as yet fed on the fox. In all likelihood there was a tremendous struggle between owl and fox and I suspect the owl was temporarily resting before commencing to feed. I have seen Snowy Owls sit on jack rabbits or even mice for several minutes before starting to feed. I suspect this owl was doing the same and was interrupted before it had the opportunity to commence its feast."

Editorial Note: An observation of another encounter between a Snowy Owl and a Red Fox made only 17 miles west of Morris may provide the basis for interpreting the successful predation described by C. C. Dixon. 